\title{
Review on Measuring Land use and Land Value Changes in Ethiopia
}

\section{Abera $\mathrm{WM}^{1 *}$ and Mehari $\mathrm{BA}^{2}$}

${ }^{1}$ Faculty of Agriculture and Environmental Sciences, Debre Tabor University, Ethiopia

${ }^{2}$ Faculty of Agriculture and Environmental Sciences, Debre Markos University, Ethiopia

\begin{abstract}
Land one of the basic implication starting place community prosperity and societal standing community in the globe. Like in many other developing countries, due to the urbanization, infrastructure expands and results into the land use and values are change. The problem is even more critical in towns and cities of the country where there is high rate of population growth and expanding of infrastructure. The purpose of this review to assess the land use and value change.
\end{abstract}

Keywords: Land use; Land value; Measuring land; Land value changes

\section{Introduction}

Land one of the basic implication starting place community prosperity and societal standing Community in the globe. Likewise land has special significance in the livelihood of Ethiopian community as it is most important finally wellbeing that allows citizens to afford their basic necessities. Urban land use is the physical manifestation of social economic cultural political and environmental forces shaping the use of land in urban area. The spatial nature of proportion of land uses in urban area is largely influenced by the national polices and economy such as housing policy industrial policy and development of communication technologies. Land use in villages around metropolises, especially in fertile areas such as Gondar city, is experiencing basic changes. The urban land use change is complex phenomenon differing greatly from place to place. The cases modify take account alternative legislation, government policy and plans, conclusion build up or transportation entrepreneurs, environment [1].

Earth it personality availability of technology to develop the land urban growth it had also alter the pattern of land use and the land value with in an urban area as well as intensity of the site use. Growth brings more activities and person in to the urban area in search of sites. So concerning more workers, machines and buildings in that area. This necessarily requires some readjustment to existing uses of land and those lower order uses find that they become sub -marginally. The increased demand for sites arising from urban growth has made it profitable to demolish existing buildings and redevelop in a new, higher order use [2].

Spreading out take position secure nearness position greater location graters ease of understanding and takes the form of secondary stricter by advanced solitary. This may bring about a change in use, say from residential to offices, or it may represent rebuilding in the same use but to a more intensive level. Such redevelopment necessities considerable changes in the physical framework of an urban area and comes about after the pressure of demand has been increasing for long period of time. A transportation improvement may improve accessibility to a particular area, increasing the premium commercial, industrial and residential users are willing to pay for the property. In this scenario, land values within the region of improved accessibility would appreciate significantly. Gondar city is located Ethiopia developing countries that it has been experiencing rapid agricultural land use transformation to urban expansion due to many infrastructural projects. In Gondar metropolitan area in the year 2011 new road was constructed and in marakisub city and AzezoTeklehymanotkebele. Drawn of the road agriculture in the access some significantly influenced earth utilize pattern changed and to the worth the earth [3].

\section{Land Management, Land Use, Land Use Change, Land Use and Value Change}

\section{Land management}

Is the sequence by earnings which the property of earth high-quality achieves? It covers the commotion disturbed with the managements of earth as an asset in cooperation beginning a natural and cost-effective point of view. It as well as agriculture activity, stone taking out, possessions and land administer.

It embraces or contains such matters as:

- Possessions transportation, as well as decision and speculation.

- Property assessment and assessment.

- The advance and supervision of utilities and services.

- The administration of land possessions like forestry, soils, or agriculture.

- The configuration and accomplishment of land-use policies.

- Environmental impact assessment.

- The keep an eye on of all behavior on land that affects the best use of that land.

\section{Land use}

Consider the height of spatial accumulation of behavior and their connected level of mobility requirements. It commonly linked with demographic and economic attributes.

\section{Land use change}

Is definite as the modification of terra firma use outstanding to human being involvement for an assortment of purpose, such as

*Corresponding author: Abera WM, Faculty of Agriculture and Environmental Sciences, Debre Tabor University, Ethiopia, Tel: 0913986518; E-mail: melese1980@gmail.com

Recieved October 27, 2017; Accepted November 15, 2017; Published November 25,2017

Citation: Abera WM, Mehari BA (2017) Review on Measuring Land use and Land Value Changes in Ethiopia. J Entrepren Organiz Manag 6: 220. doi: 10.4172/2169026X.1000220

Copyright: (c) 2017 Abera WM, et al. This is an open-access article distributed under the terms of the Creative Commons Attribution License, which permits unrestricted use, distribution, and reproduction in any medium, provided the original author and source are credited. 
for cultivation, arrangement, haulage, road and rail network and industrialized, playing field leisure use, removal and fishery.

There has been a great deal discuss concerning the natural world of the connection between transport and ground use. Frequent studies have examine the collision of transport on land use by study the trade and industry and social impact of transport savings. Augment in ease of understanding may then influence land development. Prearranged the transportation and pleasant appearance elements of the ease of understanding calculate, locations with high accessibility are easier to get to and more good-looking as destination family member to other location [4-6].

\section{Land use and value change}

Mutual dependence between the city and its surrounding villages had changed rural perspective to urban one and it leads to change rural functions and structures to urbanization it also suitable to lease system for different land use plan.

The inhabitants greater than ever as you would look forward to creates fine-tuning and readjustment of human and terra firma use movement in space surrounded by municipal coordination thus cause imaginative and structural change. earth use modernize are indirect end result of nationwide trade and manufacturing growth, it is important to evaluate land use change in the regional and local context in order to assist in anticipating the impacts associated with change and contribute to an sympathetic of productive surroundings sustainability [7].

\section{Factors Affecting Land Use Change}

Urban land use is the physical manifestation of social economic cultural political and environmental forces shaping the use of land in urban area. The spatial nature of proportion of land uses in urban area is largely influenced by the national polices and economy such as housing, industrial policy and development of communication technologies. Urban land use change is a complex in place to place.

These cases of modification like individual choice, legislation, government policy and plans decision of developer or transportation entrepreneurs, or availability of technology to develop the land urban growth it will also alter the pattern of land use and the land value within an urban area as well as intensity of the land use.

\section{Factors of land value change}

According to economic theory, land values are strong-minded by the marketplace military of contribute and stipulate. In addition however, there are other factors that influence land values such as population growth, development controls, social factors, physical attributes, speculation purposes and accessibility.

- Communications extension like transfer, Market, settlement, communal Service, and clandestine companionship.

- Undeveloped growth like enduring Cultivation, uneven farming, livestock ranching and migration.

- Demographic factor similar to normal add to, relocation, and inhabitants thickness.

- Educational factor like community and attitude, human being and family performance (cool about possessions, rent-seeking).

- Policy and Institutional Factors like formal Policies (economic development, credit) and Investment policies which expand industries factories and agro processing.
- Technical factor akin to Agro technological modify (strengthening) and farming construction reason.

- Economic factor resembling announces intensification and Commercialization, financial arrangement urbanization and significance increase.

\section{Factors affecting the value of property}

When we consider about the value of properties in the town relating to different purposes and their relation to the road upgrading some authors describes as follows. As taught in real property valuation and taxation; theories and practices, module reader Value of property changes as market conditions change, whether through economic, political, social, or legal influences. Accordingly when we come to the parcel of land every parcel is unique, at least with respect to location, because of its immobility. Different parcels can be similar, but they are never identical. Even two parcels with identical physical characteristics are still differentiated by location [8].

As indicated in Basic Principles of Land/Property value/ is not constant as various forces lead to a constantly changing marketplace. Those forces include the government, general economic activity, societal and physical forces. This fluid situation leads to a market where value is inconstant. Market value estimates are made as of a certain date, the value before or after this date is likely to differ.

\section{Relation between Road Infrastructure, Land Use and Value Change}

The necessity of municipal infrastructures and Road and its progression while the empirical part will have the relation between road expansion and economic development, Factors affecting the value of property, the role of government due developing municipal infrastructure and Measures taken to overcome challenges related with urban infrastructures.

- Terrain is predetermined in make available and its assessment enlarge starting moment in time parallel with the add two of inhabitants.

- It is a dependable and gains sufficient progressive income of confined community government to make available community utilities and infrastructures approximating teaching, physical condition middle, irrigate electrical energy and others.

- Request home \& out of the country investor who can generate employ opportunity for populace and bring in new technology.

- Most important \& progressive self-supporting income reserve.

- Impartial, politically appetizing and appropriate in multi ethnic civilization.

- Citizens share the value of common property indirectly.

- It power local-regional governments' association.

\section{The Concept of Property Value}

The concept of charge and price were for the most ingredients reputable by standard trade and industry. Terra firma superiority and aloofness, financial theory explains when a highway is initially built; large parcels of land that previously had poor accessibility or none at all are suddenly underpriced. Over and over again, the market without wildcat strike act in response: the section is speedily developed and the real estate market establishes a new equilibrium base on the new 
shipping knowledge. The land-value crash that is well-informed be able to be important.

The value of the property is the market value to be determined by the Real Estate Valuation Commission established by the Ministry of Economy and Finance (MEF) where land is the major property and its demand will enhance with the growth of governmental service delivery such as infrastructure (road) consequently the ability of land to produce services to the urban user [9-12].

\section{The relation between road expansion and economic development}

In the definition about value of property on land, property taxes on land and land. The demand for urban land will also increase when growth in government services enhances Superior Street represent enhanced production. Eye-catching communal breathing space and improved intended streets be not just artistic or security improvement. Enhanced street pull towards you additional citizens and extra movement, thus intensification in cooperation communities, the business that serve up them and the city's cost-cutting measure as a whole [13].

As indicated in study of median housing prices and monthly rents in the San Francisco Bay Area, show a physically prevailing optimistic friendship between ease of sympathetic and terra firma price, after calculating for a wide multiplicity of other variables, together with parcel size and four-sided figure video footage of expansion.

The development of urban infrastructure and industry is the key strategy to enhance the capacity of city administrations in order to plan, provide and manage the supply of urban infrastructure and services. "Investments in urban areas have to consider the role and importance of cities in regional and national social economic development. Infrastructure development should create conducive environment to accelerated economic development and equitable distribution of services," he added.

It is obvious that well-planned urban growth provide people with interest based resources that could be tool to lessen socio economic problems in the cities while poorly managed systems of operating urban infrastructure will hung up the urban socio economic growth due to mismanagement of those infrastructures constructed with the side of resource scarcity. Carefully planned and constructed municipal infrastructure can allow for very useful networks that may contribute to the living convenience for the different social classes as well as rapid economic transformation in the towns.

This arranging of networks at which municipal infrastructures managed will be the means even to enhance the annual revenues collected by municipalities from different businesses in the cities and will open an opportunity to raise the terrain charge none land properties such as buildings at most [14-16].

\section{The role of government due developing municipal infrastructure}

Urban infrastructure provision has been one of the major tasks of central and local urban governments. Providing adequate infrastructure service and facilities constitutes the fundamental question for fulfillment of urban development in many of the developing and developed nation of the world. The fulfillment of urban infrastructure has a direct relation with local and national economic growth. Many authors have argued that how far is the relation between municipal infrastructures specially roads and economic growth in their different studies.

\section{Road and its progression}

The primary ground infrastructure take their genesis as of trail which be usually used to budge from one run after subject to another with the appearance of the original form of nation-states trail in advancement to be hand-me-down for lucrative purposes as trade lengthened and some become infrastructure, chiefly on or after side to surface the domestication of flora and fauna such as horses, mules and camels. By 3,000 BC the primary cemented road systems appeared in Mesopotamia and asphalt was used to pave roads in Babylon by 625 BC. The Persian Empire had a road of at the level of government offices; however, the first institution in charge of transportation was the 2,300 $\mathrm{km}$ in the 5 th century BC. However, the first main road system was established by the Roman Empire from 300 BC and over and done, mainly for economic, military and administrative reasons. It relied on solid road manufacturing methods, including the laying of foundations and the construction of bridges. This was also connected with the organization of pan-continental trading routes, such as the Silk Road, between Europe and Asia by 100 BC.

In Ethiopia case as in sighted in the role of the convey division in Ethiopia's trade and industry growth. Street convey management government department, which was recognized in 1960. The development of the convey sector, is of wonderful monetary, community and supporting benefit while the way is the means.

Before ten year, in Ethiopia the high level of deterioration of the country road infrastructure and the lack of accessibility gain identified at one of the main challenges for government effort to achieve development. As an affect the stipulation of first-class communications was more and more emphasize on the policy formulate. Roads are accredited in the ADLI as well as sustainable development and poverty decrease automatic (SDRP) and its successor, the Plan for accelerated Sustainable Development to End Poverty (PSDEP) as well as Road Sector Development Programmed (RSDP) were policies and strategies formulated by government to improve road infrastructure [17].

As it has been stated in Ethiopian enlargement and alteration diagram planned course ornamental development and promotion eminence of communications advance is single of the pillar of Ethiopia's approach for at the bottom of the express and multi-ethnic enlargement and it is factual that the achievement of expansion strategy a great deal depends on the competence of the convey sector in general and road sub-sector in particular. Thus due accent should be given to the road growth sector so as to decode the national progress plan in to practice. Recognize the result of the road transport in development of the nationally buy and sell and industry and social performance; the Government of Ethiopia has emotionally involved a high main concern to cultivating the thoroughfare infrastructure, which was reflected in the Road Sector Development Programs (RSDP) launch since 1997 [18].

\section{Measures taken overcome challenges related with urban}

Infrastructures argue that the concept of project finance is widely used in business and finance in developed countries. However; these structures have on feature in common. The financing is not primary dependent on credit support of the sponsors of value of the physical assets involved. Thus, project finance is useful techniques for sponsors who wish to avoid having the projects debt reflected on their balance sheets to avoid the conditions or when the sponsor's credit worthiness or borrowing capacity is less than adequate. 


\section{Practices about the Impact of Roads Expansion to Property Value in the Urban Area}

\section{American experience}

As point toward in the learning by the transfer branch of Network city on the subject of the financial reimbursement of sustainable street New York City has been a person in accuse in create new model for sustainable city growth, from a five-borough monetary expansion approach to additional energy-efficient building to plentiful victorious.

It as well describe that resolve city challenge has turn out to be the key to address international challenge: how can town area be rehabilitated into anywhere a greater part of human race at present life and an bulky divide up of trade and industry commotion takes place, provide somewhere to stay population enlargement and get better economic instance all at the same time as civilizing communal physical situation, ecological sustainability and worth of days somewhere harms of community transportation is one of the city challenge and street is the main. The essential theory spoken under the heading of street and trade and industry power is that change in voyage pattern, expenses patterns and district attractiveness cause by change in the street environs can impact businesses' and goods owners' underneath lines, most unswervingly by affecting retail sales but also by pitiful, among other things, put on the open advertise charge office rents, and profitable possessions principles.

There is a rising gratitude in the middle of the public that transportation systems can have both positive and negative impact on the town surroundings they occupy that the relationship between the two is interactive, not unidirectional and of the consequence and power of transport to silhouette the city. In this up-to-the-minute view, metropolitan should plan their convey organization to help spur the type of development and excellence of life that they'd like to see to a convinced degree than the established development and engineering assumption that the context is "set" and has convinced provisions that the transportation system needs to meet health initiatives.

As stated under the title of Streets and Economic Vitality about the connection between changes in street design or operation and the economic vitality of neighborhoods? The basic hypothesis is that changes in travel patterns, spending patterns and neighborhood desirability caused by changes in the street environment can impact businesses' and property owners' bottom lines, most directly by affecting retail sales but also by affecting, among other things, retail rents, office rents, and commercial property values.

Finally, the social and economic revitalization of urban centers means that the local impacts of transportation decisions are of vital interest not simply to local people but to the metropolis as an entire [19].

\section{Ethiopian experience}

The financing for infrastructure development in developing countries came from government sources such as the host country government, multilateral institutions and export financing agencies. Recently, however, public findings emerged. In this new world, more reliance is placed on the private sector, in both developing and industrialized countries as government accept that private sectors is often better able to develop, construct and operate large scale infrastructure projects. Government believes that while infrastructure development activities are carried out, there may be the potential to create wide range of job opportunities and promote micro and small enterprise development which initiates more urban economic transformation. More over a quality of life for residents is determined by the accessibility of different infrastructures those have a relevant contribution with their daily life while there has been many challenges regarding to in the past history.

To pass through critical problems in planning and practicing about the emerging of different municipal infrastructures Ethiopia also has designed a number of plans, guide the development of both urban and rural areas as growth and revolution plan (GTP) by Ministry of Finance and Economic Development (MoFED), 2010 is one of those. The practice of these policies and plans has a significant role even if not as much as wanted where the town I am going to study about is also on the way of implementing the plan.

As stated in Country Profile: Ethiopia, (2005) 75 percent of government spending on infrastructure is targeted at improving the road network hence the transport network is quite limited and needs both upgrades and expansion. Additionally as indicated in Country Profile: Ethiopia, (2005) 75 percent of government spending on infrastructure is targeted at improving the road network. Also indicated in Ethiopia Second Urban Local Government Development Program (ULGDP II) PforR February 20, 2014 to date, 33\% of ULGDP funds have been invested in cobblestone roads, $15 \%$ on drainage and $10 \%$ on gravel roads, with the remaining $43 \%$ on a range of other urban infrastructure investments. Contributing to future local economic development.

To realize more the potential contribution of expansion of infrastructure in the towns and cities to the economic and social development, the development and expansion of infrastructure has to be undertaken through the joint and coordinated efforts of the government, private sector and the public.

\section{Policy Framework for Land Use in Ethiopia}

\section{During the hailesilasie regime (1930-1974)}

During hailesilssie 1930-1974, land was payable by the minority elite feudal lords and urban property-owner making the preponderance of the population their tenants. The rights of ownership of land in cooperation for own use, for rental fee, and conjecture were documented as inalienable rights of every constituent of society, notwithstanding the information that the a very small number of elite decision members benefited from this mode of landownership, feudal and their follower take large plot of land as much as they can.

Also land was granted to individual's peasants, which was then allowable to use, rent, and inherit relations members. And peasants were obliged to pay dissimilar kind of terrain related taxes, usually paid in kind.

\section{During the derg regime}

The derg armed government depose haileselassie in 1974, and go behind the communist domination financial system bring to an end feudal the social order and land lord-tenant rapport but permissible private ownership of land for own use and in authenticity give landownership designation free of lay the blame on merely collect taxes on modest performance and expansion on land. But, start its opposition by confiscate private material commodities (supplementary house) to outward appearance the same nation by making the wealthy underprivileged, and nationalized all land claim that all land is communal property to be give out with according to system and system 
formulate by the circumstance claim that the condition is the protector of community happiness.

\section{During the EPRDF regime}

EPRDF overthrow the derg management (collective armed totalitarianism) in May 1991. The two in front of regime who have gave basic and incessant time to the a minute figure of elite and their relations to advantage as of terra firma; communal frequent goods: unindustrialized, suburban, developed and withdrawal site, whereas grudging the outstanding man citizens from such ordinary opportunity correct right of entrance for make use of and profit.

The up to date government complementary the previous two administration, wholly pole separately set of ground use policy, country \& built-up earth reform, that transfigure land investment/employ human rights organization, might caress the passageway of prime of existence and secluded and resonance the same legitimate rights of civilization, (men \& women), accurate of entry to terra firma use, keep hold of the charge of widespread property; terra firma, for general use and enhance government income on or subsequent to responsible and progressive foundation of revenue.

The corresponding right to ground preserve in the public declaration No. 1/1995 institution in part of script 40, \#3states: "The accurate to ownership of country and urban terra firma, as healthy as of each and every one unsurprising belongings, is wholly vested in the State and in the peoples of Ethiopia. Land is a common property of the Nations, Nationalities and Peoples of Ethiopia and shall not be subject to sale or to other means of swap over." And the relationship to land narrowed to a lessee-leaser (tenant -property-owner/state) liaison, and can create confident steps to reduce the gap causes between "advancement and deficiency" (undeserved affluence and underprivileged).

The dreadfully crucial activity hire out terra firma for the maximum bidders, applied in Ethiopia, to reduce poverty, unemployment, secure equal rights of its citizens to land use and its usual opportunity, which is decided by creator to all human being uniformly. And collecting its worth of terra firma for widespread benefit; that vowed with 1/1995 constitution public statement editorial 41\#3/ states: "Every Ethiopian countrywide has the right to equal access to in public fund social overhaul" And with inner-city earth lease announcement 721/2011, part two primary principle of lease \#1/ "The correct to make use of community earth by rental fee shall be allowable in order to become cognizant the widespread attention and expansion of the populace".

Terra firma rent public statement has set dissimilar lease era for inhabited, industrials, etc. the period depends upon the reason of earth use, the lease period collection from 60-99 years. The lease payment amount depends charming every district, other than the primary downward imbursement not a smaller amount than $10 \%$, the terrific compensation will be per annum throughout lease period. Ethiopia can be a representation to LDC and the earth, a territory step to lessen insufficiency, by adopt progressive profits structure and secure citizens one and the equivalent correct to the use of land for expansion, by creation land widespread property, and create land unbiased, dependable and progressive income basis.

\section{Research Gap}

There was not an efficient study that clarified about the relation and an integration of government and society in the role of infrastructure expansion. In addition there was no attention in general so as to identify the specific role of road upgrading to property value change which not ends with multi results toward the society and government Role of new road to urban property value improve. Therefore, the research was assess the land use change and value the current status of road expansion and upgrading the changes on property value followed by, assesses the different alternative ways and measures to be taken for more achievements and was tried to address about its positive implication to the tax collected in the town from different types of buildings.

\section{Conclusions}

Urban infrastructure provision has many advantages in urban context that benefited people's quality of life. Even though there were multiple functions of urban infrastructure provision are reasonably well developed, but these was not common understanding among the stakeholders to become further accountable about in the urban coming plan, activities and management process. Developments of urban infrastructure specially road need to consider interdisciplinary and integrative approaches such as economic, social and political management and planning aspects to improve existing urban road facilities and services and to optimize urban infrastructure provision policies.

Both in developed and developing countries, there are various constraints in the urban infrastructure development and management. The government couldn't play a significant role on the issue of tax collecting which is proportional to property value improved seen in urban areas. Challenges of qualified urban infrastructure expansion development and management are high in developing countries when we compare to developed ones.

Some of the main problems in future infrastructure expansion process of cities of developing countries are proper utilization of society, population pressure that lead to activities of satisfying the basic needs, lack of balanced revenue collecting from improved property value for more investments, low resource base of institutions on infrastructure expansion, lack of priority to roads, the influence of poverty, corruption, uncooperative attitudes of the local people and concerned stakeholders, non-availability of information to the society about the benefits of infrastructure expansion planning monitoring and evaluating processes etc.

Beside the problems there are some advantages that the city could attain. In country case, in addition to making the urban area suitable for life the cities became more attractive for further investments. Therefore the researcher conducted assess the land use change and value and opportunities due to the infrastructure expansion and its contribution to the impacts on economic value of properties in study area by comparing and contrasting the results with studies conducted by different scholars on this issue.

\section{References}

1. Estache A, Garsous G (2012) IFC Economics Notes Note 1 The impact of infrastructure on growth in developing countries.

2. Alemu YB (2012) Expropriation, valuation and compensation practice in Ethiopia: The case of Bahir Dar City and Surrounding. Property Management 31: 132-158.

3. Enhancing Land Use Efficiency through Appropriate Land Policies in Ethiopia John M. Cohen \& Peter H. Koehn: Rural and Urban Land Reform in Ethiopia, April 1978

4. Ethiopia, its Land Laws and the Potential to Improve Lives "Progress \& Poverty", 1879, Henry George.

5. Shiferaw A, Soderbom M, Siba E, Alemu G (2012) Road Infrastructure and Enterprise Development in Ethiopia. The International Growth Centre. 
Citation: Abera WM, Mehari BA (2017) Review on Measuring Land use and Land Value Changes in Ethiopia. J Entrepren Organiz Manag 6: 220. doi: 10.4172/2169-026X.1000220

Page 6 of 6

6. Bello IK, Arowosegbe OS (2014) Factors affecting Land-Use Change on Property Values in Nigeria. Journal of Research Economics and Internationa Finance 3: 79-82.

7. Geophilos: Gail Warden; Spring 2001 No. 01 (1)/Additional information Ethiopian 1995 constitution.

8. Growth and Transformation plan (GTP), 2010/11-2014/15 Draft Minister of Finance and Economic Development (MoFED) November (2010) Addis Ababa.

9. Gondar City Administration Revenue Office (2016) 2016/17 Result Based Strategic Plan, Gondar.

10. El-Barmelgy MM, Shalaby AM, Nassar UA, Ali SM (2014) Economic land use theory and land value in value model. International Journal of Economics and Statistics 2: 91-98.

11. Kothar CR (1995) Research Methodology, Methods and Techniques. Wishwa Prakashan, Division of Wiley Eastern Limited, New Delhi.

12. Adebayo MA (2009) Impact of urban land use changes on property values in Metropolitan Lagos. The Social Sciences 4: 111-117.
13. Francis ND (2010) The impact of transportation Infrastructure Upgrading on Patterns of Land Use: A Case Study of the Eastern Bypass.

14. O'Sullivan E (1999) Research Methods for Public Administrators. Third Edition, University of North Carolina at Cbarlotter An imprint Addison Weeley Long man. Inc.

15. Perera MH (1990) Framework for classifying and evaluating economic impacts caused by a transportation improvement. Transportation Research Record 1274.

16. Shiferaw A, Soderbom M, Siba E, Alemu G (2012) Road Infrastructure and Enterprise Development in Ethiopia (Working Paper).

17. Holden TS, Bezu S (2014) Land Valuation and Perceptions of Land Sales Prohibition in Ethiopia.

18. Tadesse KK (2002) Five Thousand Years of Sustainability? A case study on Gedeo land use. PhD Thesis Wageningen University.

19. www.earthexplorer/glovies.US 